\title{
Utilization of $N$-Bromosuccinimide as a Brominating Agent for the Determination of Sumatriptan Succinate in Bulk Drug and Tablets
}

\author{
Kudige N. Prashanth, Kanakapura Basavaiah, and Madihalli S. Raghu \\ Department of Chemistry, University of Mysore, Manasagangotri, Mysore, Karnataka 570006, India \\ Correspondence should be addressed to Kanakapura Basavaiah; kanakapurabasavaiah@gmail.com
}

Received 27 February 2013; Accepted 16 June 2013

Academic Editor: Jan Åke Jönsson

Copyright (C) 2013 Kudige N. Prashanth et al. This is an open access article distributed under the Creative Commons Attribution License, which permits unrestricted use, distribution, and reproduction in any medium, provided the original work is properly cited.

\begin{abstract}
One titrimetric and two spectrophotometric methods which are simple, sensitive, and economic are described for the determination of sumatriptan succinate (STS) in bulk drug and in tablet dosage form using $N$-bromosuccinimide (NBS) as a brominating agent. In titrimetry, aqueous solution of STS is treated with a measured excess of NBS in acetic acid medium, and after the bromination of STS is judged to be complete, the unreacted NBS is determined iodometrically (method A). Spectrophotometric methods entail addition of a known excess of NBS in acid medium followed by the determination of residual NBS by its reaction with excess iodide, and the liberated iodine $\left(\mathrm{I}_{3}{ }^{-}\right)$is either measured at $370 \mathrm{~nm}$ (method B) or liberated iodine is reacted with starch followed by the measurement of the blue colored starch-iodine complex at $570 \mathrm{~nm}$ (method C). Titrimetric method is applicable over range $1.0-10.0 \mathrm{mg}$ STS (method A), and the reaction stoichiometry is found to be $1: 3$ (STS : NBS). The spectrophotometric methods obey Beer's law for concentration range $0.6-15.0 \mu \mathrm{g} \mathrm{mL}^{-1}$ (method B) and $0.2-4.0 \mu \mathrm{g} \mathrm{mL}^{-1}$ (method C). The calculated apparent molar absorptivity values were found to be $2.10 \times 10^{4}$ and $7.44 \times 10^{4} \mathrm{~L} \mathrm{~mol}^{-1} \mathrm{~cm}^{-1}$, for method B and method C, respectively.
\end{abstract}

\section{Introduction}

Triptans are a group of tryptamine-based drugs used in the acute treatment of migraine headaches. Sumatriptan succinate (Figure 1) is one among them and is structurally related to the neurotransmitter serotonin. Sumatriptan succinate (STS) is a 5-hydroxytryptamine (5-HT) receptor subtype (a member of the 5-HT 1D family) having only a week affinity for $5-\mathrm{HT}_{1 \mathrm{~A}}, 5-\mathrm{HT}_{5 \mathrm{~A}}$, and $5-\mathrm{HT}_{7}$ receptors and chemically designated as [3-[2-(dimethylamino)ethyl]-1H-indol-5-yl]$\mathrm{N}$-methylmethanesulphonamide hydrogen butanedioate [1]. STS acts by selectively binding to serotonin type-1D receptors (serotonin agonist) and rapidly terminates a migraine attack while eliminating associated symptoms such as nausea, vomiting, and light and sound sensitivity [2].

STS has official monographs in BP [1], EP [3], and USP [4] which describe liquid chromatographic methods for the assay of STS. From the literature survey, it is found that high performance liquid chromatography (HPLC) has been used for the assay of STS in human plasma $[5,6]$, human serum [7], rabbit plasma [8], and human plasma and urine [9] whereas liquid chromatography-mass spectrophotometry is used (LC-MS/MS) in body fluids [10] and human plasma [11]. Several methods have been reported for the determination of STS in pharmaceuticals and include UV-spectrophotometry [12-16], HPLC [17-20], ultra performance liquid chromatography (UPLC) [21], high performance thin layer chromatography (HPTLC) [16, 22], capillary electrophoresis [23], micellar electrokinetic chromatography [24], and voltammetry [25-27].

Besides, STS in pharmaceuticals is reported to have been determined by visible spectrophotometry employing different reaction schemes. Two methods were reported by Kalyanaramu and Raghubabu [28]; first method was based on oxidative coupling of STS with brucine in presence of sodium metaperiodate, and the second method was based on the formation of internal salt between drug and aconitic anhydride, dehydration product of citric acid with acetic 


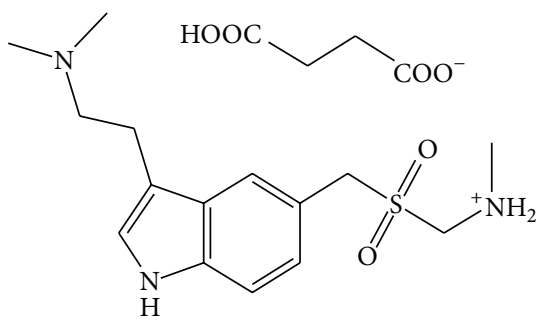

FIGURE 1: Structure of STS.

anhydride. The same authors reported a method based on the formation of inner molecular complex between drug and sodium nitroprusside in acetaldehyde [29]. A green colored ternary complex formed by the drug with cobalt-thiocyanate was extracted into benzene and measured at $630 \mathrm{~nm}$ and served as the basis of its assay [30]. Tropaeolin 000 is reported to form chloroform extractable orange-colored ion-pair with STS having an absorption maximum at $483 \mathrm{~nm}$, and this was used for the sensitive assay of the drug by Kalyanaramu and Raghubabu [31].

Kalyanaramu et al. [32] reported two methods based on charge transfer reaction. The first method is based on the formation of charge transfer complex between the drug and chloranil, while the second method is based on the interaction of $\mathrm{N}$-alkyl vinyl amine formed from the condensation of the free secondary amine group in the drug and acetaldehyde with p-chloranil to give vinyl amino substituted quinone. Fathima et al. [33] reported a method based on C-T complexation reaction of drug with $\mathrm{p}$-chloranilic acid. The reaction between STS and sodium salt of 1,2-naphthaquinone4-sulphonic acid (Folin reagent) yielded a brown colored chromogen [34] forming the basis for the assay of the drug. Based on a well-known redox reaction and employing Folin-Ciocalteu's reagent [35], the drug in pharmaceutical dosage forms was determined by Tipre and Vivia. Satyanarayana and Rao [36] have described two methods using the reaction between drug and in situ bromine and the unreacted bromine measured either by methyl orange or indigo carmine.

No titrimetric method was found in the literature for the quantification of STS in pharmaceuticals. The reported visible spectrophotometric methods suffer from one or more disadvantages such as rigid $\mathrm{pH}$ control, heating and/or extraction step, use of multistep reaction/s, longer contact time, less stable colored species, and narrow linear dynamic range as indicated in Table 1 .

The present paper describes one titrimetric and two visible spectrophotometric methods based on the bromination reaction by NBS. Simplicity, sensitivity, wide linear ranges, mild experimental conditions, and above all costeffectiveness characterize the proposed methods. Optimum conditions were established and all the methods were validated according to ICH guidelines. The validated methods when applied to the determination of STS in tablets yielded results which were in good agreement with the label claim.

\section{Experiment}

2.1. Apparatus. A Systronics model 106 digital spectrophotometer with $1 \mathrm{~cm}$ path length matched quartz cells was used to record the absorbance values.

2.2. Reagents and Standards. All chemicals used were of analytical reagent grade. Distilled water was used throughout the investigation.

$\mathrm{N}$-Bromosuccinimide $\left(0.01 \mathrm{M}, 200 \mu \mathrm{g} \mathrm{mL}^{-1}\right.$ and $\left.60 \mu \mathrm{g} \mathrm{mL}^{-1}\right)$. An approximately $0.01 \mathrm{M}$ solution was prepared by dissolving about $1.8 \mathrm{~g}$ of NBS (SRL Research Chemicals, Mumbai, India) in water with the aid of heat and diluted to one liter water. The solution was standardized iodometrically [37] and kept in an amber colored bottle and stored in a refrigerator and used in titrimetry. It was diluted appropriately to get working concentrations of 200 and $60 \mu \mathrm{g} \mathrm{mL}^{-1} \mathrm{NBS}$ for use in spectrophotometric method B and method C, respectively.

Potassium Iodide. A 5\% potassium iodide (Merck, Mumbai, India) solution was prepared by dissolving $5 \mathrm{~g}$ potassium iodide with water in a $100 \mathrm{~mL}$ calibrated flask. This solution was prepared afresh daily. A $2 \%$ solution was prepared separately for spectrophotometric work.

Starch Solution. One gram of starch (LOBA Chemie Ltd., Mumbai, India) was made into paste with water and slowly poured with constant stirring into $100 \mathrm{~mL}$ boiling water, boiled for $5 \mathrm{~min}$, cooled, and used. This solution was prepared freshly every day.

Hydrochloric Acid. Concentrated hydrochloric acid (Merck, Mumbai, India, Sp. gr. 1.18) was diluted appropriately with water to get $2 \mathrm{M} \mathrm{HCl}$ for use in all the methods.

Sodium Acetate. A $3 \mathrm{M}$ aqueous solution of sodium acetate was prepared by dissolving suitable quantity of sodium acetate trihydrate crystals (Merck, Mumbai, India) in water for use in spectrophotometric method B.

Standard Solution of STS. Pharmaceutical grade sumatriptan succinate sample (purity 99.5\%) was received from MSN laboratories, Hyderabad, India, as gift sample and was used as received. A stock standard solution equivalent to $1.0 \mathrm{mg} \mathrm{mL}^{-1}$ of STS was prepared by dissolving accurately weighed $250 \mathrm{mg}$ of pure drug in water and diluted to mark in a $250 \mathrm{~mL}$ calibrated flask with the same solvent. The solution $\left(1 \mathrm{mg} \mathrm{mL}^{-1}\right.$ STS) was used in titrimetric work and diluted appropriately with water to get the working concentrations of 30 and $10 \mu \mathrm{g} \mathrm{mL}^{-1}$ STS for use in spectrophotometric method B and method $C$, respectively.

Two brands of tablets, namely, Suminat-25 and Suminat50 (Sun Pharmaceuticals Ltd., Sikkim, India), both were purchased from local commercial sources.

\subsection{General Procedures}

2.3.1. Titrimetry (Method A). A $10.0 \mathrm{~mL}$ aliquot of pure drug solution containing 1.0-10.0 mg of STS was measured 
TABLE 1: Comparison of the proposed and the existing visible spectrophotometric methods.

\begin{tabular}{|c|c|c|c|c|c|c|}
\hline Sl. no. & Reagent/s & Methodology & $\lambda_{\max }, \mathrm{nm}$ & $\begin{array}{c}\text { Beer's law range } \\
\mu \mathrm{g} \mathrm{mL}^{-1} \\
\left(\varepsilon \text { in } \mathrm{L} \mathrm{mol}^{-1} \mathrm{~cm}^{-1}\right) \\
\end{array}$ & Remarks & Reference \\
\hline \multirow[t]{2}{*}{1} & $\begin{array}{l}\text { (a) Brucine-sodium } \\
\text { metaperiodate }\end{array}$ & \multirow{2}{*}{$\begin{array}{l}\text { Oxidative coupling } \\
\text { product was } \\
\text { measured }\end{array}$} & 520 & $\begin{array}{l}4.0-20.0 \\
\text { NA }\end{array}$ & \multirow[t]{2}{*}{ Less sensitive, multistep reaction } & \multirow[t]{2}{*}[28]{} \\
\hline & $\begin{array}{l}\text { (b) Citric acid-acetic } \\
\text { anhydride }\end{array}$ & & 580 & $\begin{array}{l}8.0-24.0 \\
\text { NA }\end{array}$ & & \\
\hline 2 & $\begin{array}{l}\text { Sodium nitroprusside } \\
\text { acetaldehyde }\end{array}$ & $\begin{array}{l}\text { Inner molecular } \\
\text { complex formed was } \\
\text { measured }\end{array}$ & 552 & $\begin{array}{c}4.0-20.0 \\
\left(1.10 \times 10^{4}\right)\end{array}$ & $\begin{array}{l}\text { Less sensitive, requires rigid } \mathrm{pH} \\
\text { control }\end{array}$ & [29] \\
\hline 3 & Cobalt thiocyanate & $\begin{array}{l}\text { Extracted ternary } \\
\text { complex formed by } \\
\text { reaction with drug } \\
\text { was measured }\end{array}$ & 629.4 & $\begin{array}{c}16.0-48.0 \\
\left(3.97 \times 10^{3}\right)\end{array}$ & $\begin{array}{l}\text { Less sensitive, involves extraction } \\
\text { step }\end{array}$ & {$[30]$} \\
\hline 4 & Tropaeolin-OOO & $\begin{array}{l}\text { Extracted ion-pair } \\
\text { complex was } \\
\text { measured }\end{array}$ & 482.5 & $\begin{array}{c}2.0-10.0 \\
\left(2.08 \times 10^{4}\right)\end{array}$ & $\begin{array}{l}\text { Requires rigid } \mathrm{pH} \text { control; involves } \\
\text { liquid-liquid extraction; use of } \\
\text { organic solvents }\end{array}$ & {$[31]$} \\
\hline \multirow[t]{2}{*}{5} & $\begin{array}{l}\text { (a) Chloranil in } \\
\text { 1,4-dioxane }\end{array}$ & \multirow{2}{*}{$\begin{array}{l}\text { CT-complex } \\
\text { measured }\end{array}$} & 548 & $\begin{array}{c}5.0-25.0 \\
\left(1.00 \times 10^{4}\right)\end{array}$ & \multirow[t]{2}{*}{$\begin{array}{l}\text { Less sensitive, involves heating step, } \\
\text { time consuming }\end{array}$} & \multirow[t]{2}{*}[32]{} \\
\hline & $\begin{array}{l}\text { (b) Chloranil and } \\
\text { acetaldehyde }\end{array}$ & & 660 & $\begin{array}{c}20.0-60.0 \\
\left(3.19 \times 10^{4}\right)\end{array}$ & & \\
\hline 6 & p-Chloranilic acid & $\begin{array}{l}\text { CT-complex } \\
\text { measured }\end{array}$ & 520 & $\begin{array}{r}9.28 \times 10^{2} \\
20-184\end{array}$ & Less sensitive; use of organic solvents & [33] \\
\hline 7 & Folin reagent & $\begin{array}{l}\text { Chromogen formed } \\
\text { by reaction with } \\
\text { drug was measured }\end{array}$ & 455.6 & $\begin{array}{l}16.0-48.0 \\
\left(3.85 \times 10^{3}\right)\end{array}$ & $\begin{array}{l}\text { Less sensitive, strict } \mathrm{pH} \text { control, time } \\
\text { consuming }\end{array}$ & {$[34]$} \\
\hline \multirow[t]{2}{*}{8} & Folin-Ciocaltaeu reagent & $\begin{array}{l}\text { Reduced FC-reagent } \\
\text { was measured }\end{array}$ & 760 & $\begin{array}{l}2.0-6.0 \\
\text { NA }\end{array}$ & \multirow[t]{2}{*}{ Narrow linear range, less sensitive } & {$[35]$} \\
\hline & Bromate-bromide- & & & & & \\
\hline \multirow[t]{2}{*}{9} & (a) Methyl orange & $\begin{array}{l}\text { Unreacted bromine } \\
\text { was measured }\end{array}$ & 508 & $\begin{array}{c}0.2-1.6 \\
\left(1.90 \times 10^{5}\right)\end{array}$ & \multirow[t]{2}{*}{$\begin{array}{l}\text { Narrow linear range, multistep } \\
\text { reaction, time consuming }\end{array}$} & \multirow{2}{*}[36]{} \\
\hline & (b) Indigo carmine & & 610 & $\begin{array}{c}2.0-12.0 \\
\left(2.71 \times 10^{4}\right)\end{array}$ & & \\
\hline \multirow{3}{*}{10} & NBS & & & & \multirow{3}{*}{$\begin{array}{l}\text { No rigorous control of experimental } \\
\text { conditions, no heating or extraction } \\
\text { step, no use of organic solvents or } \\
\text { toxic chemicals, and sensitive with } \\
\text { wide linear dynamic range }\end{array}$} & \multirow{3}{*}{$\begin{array}{l}\text { Proposed } \\
\text { methods }\end{array}$} \\
\hline & (a) Potassium Iodide & $\begin{array}{l}\text { Tri-iodide ion } \\
\text { measured }\end{array}$ & 370 & $\begin{array}{c}0.6-15.0 \\
\left(\varepsilon=2.10 \times 10^{4}\right)\end{array}$ & & \\
\hline & $\begin{array}{l}\text { (b) Potassium } \\
\text { Iodide-starch }\end{array}$ & $\begin{array}{l}\text { Starch-iodine } \\
\text { complex measured }\end{array}$ & 570 & $\begin{array}{c}0.2-4.0 \\
\left(\varepsilon=7.44 \times 10^{4}\right)\end{array}$ & & \\
\hline
\end{tabular}

NBS: N-bromosuccinimide. NA: not available.

accurately and transferred into a $100 \mathrm{~mL}$ Erlenmeyer flask. The solution was acidified by adding $5 \mathrm{~mL}$ of $2.0 \mathrm{M} \mathrm{HCl}$. Then $10 \mathrm{~mL}$ of $0.01 \mathrm{M}$ NBS was added by means of a pipette and the flask was let stand for $15 \mathrm{~min}$ at room temperature. Lastly, $5 \mathrm{~mL}$ of $5 \% \mathrm{KI}$ was added, and after $5 \mathrm{~min}$ the liberated iodine was titrated against $0.02 \mathrm{M}$ sodium thiosulphate using $1 \mathrm{~mL}$ of $1 \%$ starch as an indicator. A blank experiment was simultaneously performed.

The amount of STS was computed from the following formula:

$$
\text { Amount }(\mathrm{mg})=\frac{(B-A) \times M_{r} \times S}{n},
$$

where $B$ is $\mathrm{mL}$ of titrant in the absence of sample, $A$ is $\mathrm{mL}$ of titrant in the presence of the sample, $M_{r}$ is relative molecular mass of drug, $S$ is strength of NBS, and $n$ is number of moles of titrant reacting with per mole of STS.

2.3.2. Spectrophotometric Method B (Based on the Measurement of Tri-Iodide Ion). Varying aliquots $(0.2-5.0 \mathrm{~mL})$ of standard STS solution $\left(30 \mu \mathrm{g} \mathrm{mL}^{-1}\right)$ were accurately transferred into a series of $10 \mathrm{~mL}$ calibrated flasks and the total volume was adjusted to $5.0 \mathrm{~mL}$ with water. One $\mathrm{mL}$ of $2 \mathrm{M}$ $\mathrm{HCl}$ was added to each flask followed by the addition of $1 \mathrm{~mL}$ NBS solution $\left(200 \mu \mathrm{g} \mathrm{mL}^{-1}\right.$ in NBS). The content was mixed well and let stand for $15 \mathrm{~min}$ with occasional shaking. Then, $1.0 \mathrm{~mL}$ of $3 \mathrm{M}$ sodium acetate solution was added to each flask followed by $1 \mathrm{~mL}$ of $2 \%$ potassium iodide. The volume was brought to the mark with water and the absorbance of 


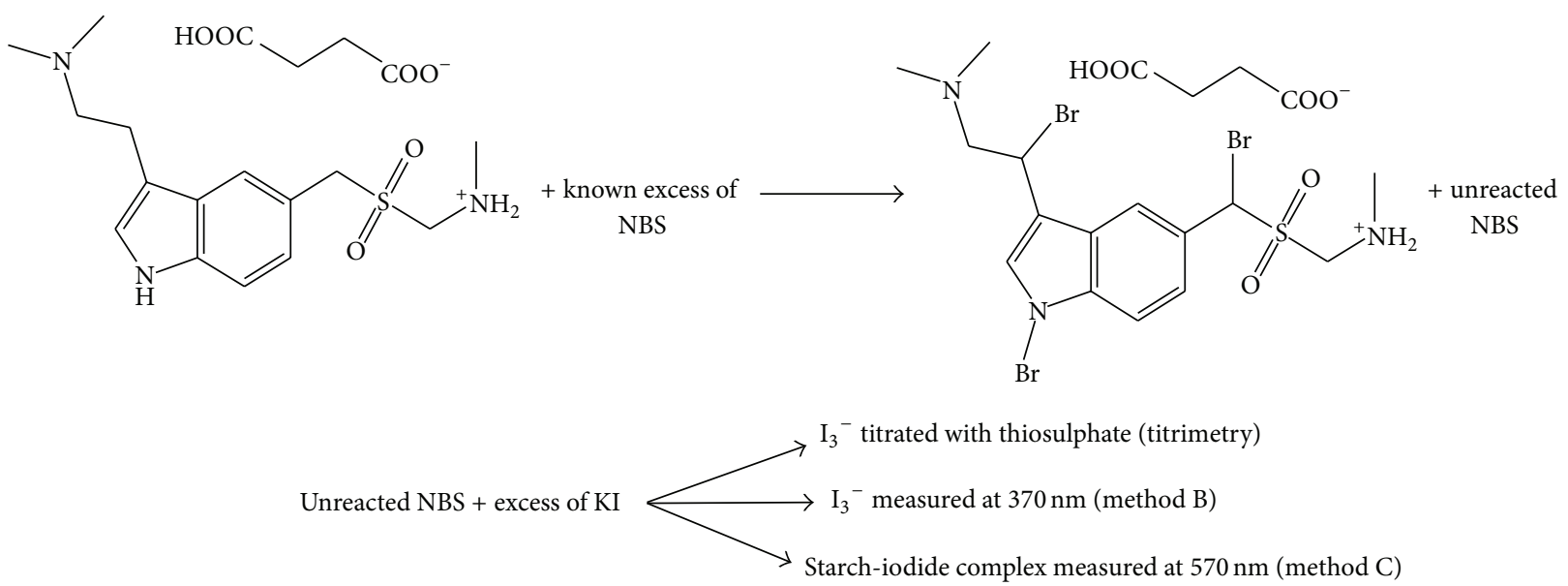

SCHEME 1: Proposed reaction pathway for the bromination of STS by NBS.

the resulting tri-iodide ion was measured at $370 \mathrm{~nm}$ after 5 min against water blank.

\subsubsection{Spectrophotometric Method C (Based on the Measure-} ment of Starch-Iodine Complex). Into a series of $10 \mathrm{~mL}$ calibrated flasks, different aliquots $(0.2-4.0 \mathrm{~mL})$ of standard STS $\left(10 \mu \mathrm{g} \mathrm{mL}^{-1}\right)$ solution were transferred using a microburette. The total volume in each flask was brought to $4 \mathrm{~mL}$ by adding required quantity of water. The solution was acidified by adding $1 \mathrm{~mL}$ of $2 \mathrm{M} \mathrm{HCl}$, and $1 \mathrm{~mL}$ of NBS $\left(60 \mu \mathrm{g} \mathrm{mL}^{-1}\right.$ in NBS) solution was then added to each flask. The flasks were kept aside for $15 \mathrm{~min}$ with periodic shaking; $1 \mathrm{~mL}$ of $2 \%$ potassium iodide was added and the content was mixed well. After $5 \mathrm{~min}, 1 \mathrm{~mL}$ of $1 \%$ starch solution was added to each flask and the volume was made up to the mark with water and mixed well. The absorbance of the resulting blue chromogen was measured at $570 \mathrm{~nm}$ against water blank after 5 min.

A standard graph was prepared by plotting absorbance against concentration and the unknown concentration was read from the graph or computed from the regression equation derived using Beer's law data.

2.3.4. Assay Procedure for Tablets. Twenty tablets each containing 25 or $50 \mathrm{mg}$ of STS were weighed accurately and ground into a fine powder. To prepare a standard stock solution of tablet, an amount of the powder equivalent to $100 \mathrm{mg}$ of STS was accurately weighed into a $100 \mathrm{~mL}$ volumetric flask, and $60 \mathrm{~mL}$ water was added and content shaken thoroughly for about $20 \mathrm{~min}$. The volume was diluted to the mark with water, mixed well, and filtered using Whatman no. 42 filter paper. First $10 \mathrm{~mL}$ portion of the filtrate was rejected and a convenient aliquot of filtrate (containing $1 \mathrm{mg} \mathrm{mL}^{-1} \mathrm{STS}$ ) was taken for assay by titrimetric procedure. Further, the standard stock solution of tablet was diluted stepwise to achieve 30 and $10 \mu \mathrm{g} \mathrm{mL}^{-1}$ of STS for use in spectrophotometric method $\mathrm{B}$ and method $\mathrm{C}$, respectively. A suitable aliquot was then subjected to analysis following the procedures described earlier.

2.3.5. Procedure for the Analysis of Placebo Blank and Synthetic Mixture. A placebo blank containing starch $(10 \mathrm{mg})$, acacia (15 mg), hydroxyl cellulose (20 mg), sodium citrate (30 mg), lactose $(10 \mathrm{mg})$, talc $(60 \mathrm{mg})$, acacia $(30 \mathrm{mg})$, magnesium stearate $(25 \mathrm{mg})$, and sodium alginate $(30 \mathrm{mg})$ was prepared, and $20 \mathrm{mg}$ of the placebo blank was extracted with water and the solution was made as described under "assay procedure for tablets" and then subjected to analysis.

A synthetic mixture was prepared by adding $50 \mathrm{mg}$ of STS to about $25 \mathrm{mg}$ of the placebo blank prepared earlier, homogenized, and the solution was prepared as done under "assay procedure for tablets." The filtrate was collected in a $50 \mathrm{~mL}$ flask. The synthetic mixture solution was analysed by titrimetry and then appropriately diluted with water to get 30.0 and $10.0 \mu \mathrm{g} \mathrm{mL}^{-1}$ STS solutions, and appropriate aliquots were subjected to analysis by method B and method C, separately.

\section{Results and Discussion}

3.1. Chemistry. NBS is widely used as an oxidizing or brominating reagent for the determination of many pharmaceutically important compounds [38-41]. It is also a specific reagent for the bromination of organic compounds at allylic position [42]. As NBS is a mild oxidizing agent, the only possible reaction between STS and NBS would be bromination at the two allylic positions and a secondary amine present in pyrrole ring present in STS. This was supported by a reaction stoichiometry of $1: 3$ between STS and NBS. The possible reaction scheme is presented in Scheme 1. The proposed methods are indirect and involve the determination of unreacted NBS after allowing the reaction between STS and a measured amount of NBS go to completion. The amount of iodine liberated, by the reaction of unreacted NBS with 


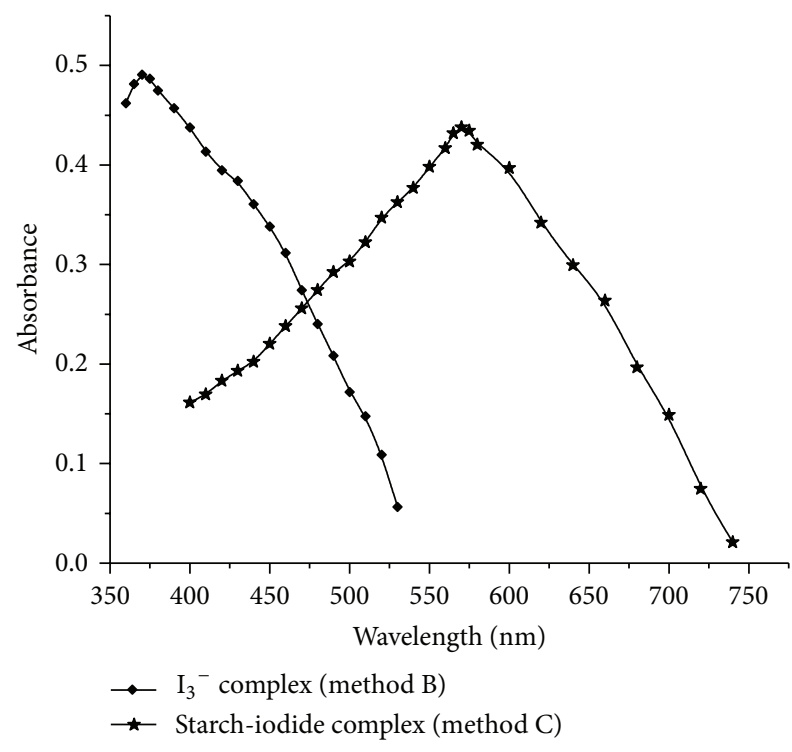

FIGURE 2: Absorption spectra: $6.0 \mu \mathrm{g} \mathrm{mL} \mathrm{m}^{-1}$ STS, tri-iodate (method B); $2.0 \mu \mathrm{g} \mathrm{mL}^{-1}$ STS, starch-iodide complex (method C).

potassium iodide, was either measured directly at $370 \mathrm{~nm}$ or reacted with starch, and resulting blue colored chromogen of starch-iodine complex was measured at $570 \mathrm{~nm}$ whereas iodometric back titration procedure was used in titrimetry.

\subsection{Optimization of Reaction Conditions}

3.2.1. Titrimetry. Direct titration of STS with NBS was not feasible due to slow reaction. In the indirect procedure, a known excess of NBS was allowed to react with STS in acid medium and the unreacted NBS was subsequently determined iodometrically. At optimum acid concentration $(5 \mathrm{~mL}$ of $2 \mathrm{M} \mathrm{HCl}$ in a total volume of $25 \mathrm{~mL}$ ), the reaction goes to completion within $15 \mathrm{~min}$. At lower acid concentration (less than $3 \mathrm{~mL}$ of $5 \mathrm{M} \mathrm{HCl}$ ) the reaction stoichiometry was slightly less and at higher acid concentration (up to $8 \mathrm{~mL}$ of $5 \mathrm{M} \mathrm{HCl}$ ) regular stoichiometry was observed. Under the optimized reaction condition, there was found to be a definite reaction stoichiometry of $1: 3$ between STS and NBS within the range of 1.0-10.0 mg STS. Contact time of 5 minute, was sufficient for the complete liberation of iodine from the unreacted NBS.

3.2.2. Spectrophotometry. In spectrophotometric methods, the amount of iodine liberated, by the reaction of unreacted bromine with potassium iodide, was either measured directly at 370 in method B or reacted with starch, and resulting blue colored chromogen of starch-iodide complex is measured at $570 \mathrm{~nm}$ for method C (Figure 2).

Optimization of NBS. To fix the optimum concentration of NBS, different concentrations of NBS were treated with a fixed concentration $(1 \mathrm{~mL} 2 \% \mathrm{KI})$ of potassium iodide in method B and potassium iodide and starch $(1 \mathrm{~mL} 1 \%$ starch) in method $\mathrm{C}$ in $\mathrm{HCl}$ medium and the absorbance

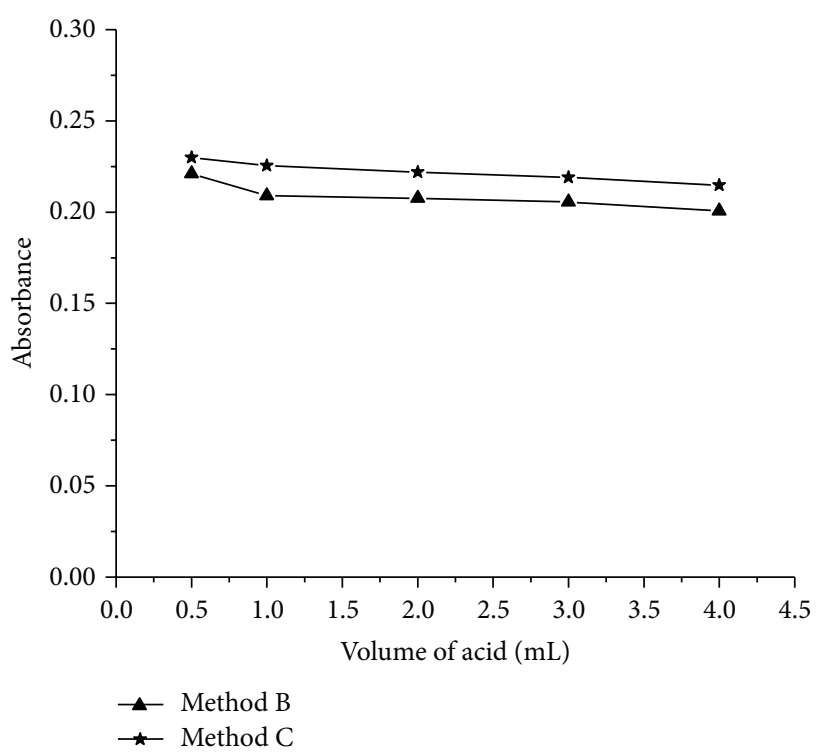

FIGURE 3: Effect acid concentration on $12 \mu \mathrm{g} \mathrm{mL}^{-1}$ STS (method B) and $3 \mu \mathrm{g} \mathrm{mL}^{-1}$ STS (method C).

was measured at $370 \mathrm{~nm}$ and $570 \mathrm{~nm}$, respectively. A constant and maximum absorbance resulted in $20 \mu \mathrm{g} \mathrm{m}^{-1} \mathrm{NBS}$ in method B and $6 \mu \mathrm{g} \mathrm{mL}^{-1}$ NBS in method C. Hence, different concentrations of STS were treated with $1 \mathrm{~mL}$ of $200 \mu \mathrm{g} \mathrm{mL}^{-1}$ NBS (method B) and $60 \mu \mathrm{g} \mathrm{mL}^{-1} \mathrm{NBS}(\operatorname{method} \mathrm{C})$ in $\mathrm{HCl}$ medium before determining the residual NBS as illustrated in the reaction Scheme 1. This facilitated the optimization of the linear dynamic ranges over which procedure could be applied for the assay of STS.

Effect of Acid Concentration. The reaction between STS and NBS was performed in different acid media. Better results were obtained in hydrochloric acid medium. The effect of acid concentration on the reaction between STS and NBS was studied by varying the concentration of $\mathrm{HCl}$ keeping the concentrations of NBS and drug fixed. The reaction was found to be rapid yielding a constant absorbance with maximum sensitivity and stability when the $\mathrm{HCl}$ concentration was maintained in the range of $0.18-0.75 \mathrm{M}(0.5$ to $3.0 \mathrm{~mL} 2 \mathrm{M}$ $\mathrm{HCl}$ ). Therefore, $1 \mathrm{~mL}$ of $2 \mathrm{M} \mathrm{HCl}$ in a total volume of $6 \mathrm{~mL}$ $(0.33 \mathrm{M})$ was used in both methods (Figure 3 ).

Reaction Time and Color Stability. The effect of time on the reaction between STS and NBS in the presence of $\mathrm{HCl}$ was studied by keeping all other reaction conditions unchanged. The absorbance of the colored species was measured after different reaction times (5.0-30.0 min) and the results showed that the reaction was complete within $15 \mathrm{~min}$ in both method B and C. The absorbance of yellow tri-iodide ion in method $\mathrm{B}$ and starch-iodide complex chromogen in method $\mathrm{C}$ remained stable for at least $1 \mathrm{hr}$.

Role of Sodium Acetate. The liberation of iodine in method $B$ did not stop even after 30 min under the specified acidic 
TABLE 2: Regression and analytical parameters.

\begin{tabular}{|c|c|c|}
\hline Parameter & Method B & Method C \\
\hline$\lambda_{\max }, \mathrm{nm}$ & 370 & 570 \\
\hline Beer's law limits, $\mu \mathrm{g} \mathrm{mL}^{-1}$ & $0.0-15.0$ & $0.0-4.0$ \\
\hline Molar absorptivity $(\varepsilon), \mathrm{L} \mathrm{mol}^{-1} \mathrm{~cm}^{-1}$ & $2.10 \times 10^{4}$ & $7.44 \times 10^{4}$ \\
\hline Sandell sensitivity ${ }^{\mathrm{a}}, \mu \mathrm{g} \mathrm{cm}^{-2}$ & 0.0197 & 0.0056 \\
\hline Limit of detection (LOD), $\mu \mathrm{g} \mathrm{mL}^{-1}$ & 0.34 & 0.07 \\
\hline Limit of quantification (LOQ), $\mu \mathrm{g} \mathrm{mL}^{-1}$ & 1.02 & 0.20 \\
\hline \multicolumn{3}{|l|}{ Regression equation, $Y^{\mathrm{b}}$} \\
\hline Intercept $(a)$ & 0.79 & 0.80 \\
\hline Slope $(b)$ & -0.049 & -0.19 \\
\hline Correlation coefficient $(r)$ & 0.9996 & 0.9997 \\
\hline Standard deviation of intercept $\left(S_{a}\right)$ & 0.074 & 0.078 \\
\hline Standard deviation of slope $\left(S_{b}\right)$ & 0.009 & 0.037 \\
\hline
\end{tabular}

TABLE 3: Evaluation of intra-day and inter-day precision and accuracy.

\begin{tabular}{|c|c|c|c|c|c|c|c|}
\hline \multirow{2}{*}{ Method } & \multirow[b]{2}{*}{ STS $^{*}$ taken } & \multicolumn{3}{|c|}{ Intra-day $(n=5)$} & \multicolumn{3}{|c|}{ Inter-day $(n=5)$} \\
\hline & & STS found ${ }^{\mathrm{a}}$ & $\% \mathrm{RSD}^{\mathrm{b}}$ & $\% \mathrm{RE}^{\mathrm{c}}$ & STS found ${ }^{\mathrm{a}}$ & $\% \mathrm{RSD}^{\mathrm{b}}$ & $\% \mathrm{RE}^{\mathrm{c}}$ \\
\hline \multirow{3}{*}{$\begin{array}{l}\text { A } \\
\text { (Titrimetry) }\end{array}$} & 4.00 & 3.98 & 0.90 & 0.55 & 3.95 & 1.39 & 1.21 \\
\hline & 6.00 & 5.99 & 0.92 & 0.23 & 6.04 & 1.09 & 0.65 \\
\hline & 8.00 & 8.05 & 0.73 & 0.59 & 8.06 & 1.06 & 0.76 \\
\hline \multirow{3}{*}{$\begin{array}{l}\text { B } \\
\text { (Spectrophotometry) }\end{array}$} & 6.00 & 6.06 & 0.97 & 0.96 & 6.08 & 1.83 & 1.42 \\
\hline & 9.00 & 9.10 & 1.04 & 1.06 & 9.12 & 1.57 & 1.32 \\
\hline & 12.0 & 11.9 & 1.02 & 0.94 & 11.9 & 1.40 & 1.12 \\
\hline \multirow{3}{*}{$\begin{array}{l}\text { C } \\
\text { (Spectrophotometry) }\end{array}$} & 1.00 & 1.02 & 1.44 & 1.55 & 1.02 & 2.20 & 1.93 \\
\hline & 2.00 & 1.98 & 0.94 & 1.14 & 1.97 & 1.37 & 1.40 \\
\hline & 3.00 & 2.97 & 0.63 & 0.85 & 2.97 & 0.91 & 1.02 \\
\hline
\end{tabular}

${ }^{*}$ In method A, STS taken/found are in $\mathrm{mg}$ and they are $\mu \mathrm{g} \mathrm{mL} \mathrm{L}^{-1}$ in methods B and C.

${ }^{a}$ Mean value of five determinations.

${ }^{\mathrm{b}}$ Relative standard deviation (\%).

${ }^{\mathrm{c}}$ Relative error (\%).

conditions, but on adding sodium acetate the reaction ceased immediately. The amount of sodium acetate required was optimized as $1 \mathrm{~mL}$ of $3 \mathrm{M}$ sodium acetate in a total volume of $10 \mathrm{~mL}$. In method $\mathrm{C}$, the reaction was ceased by optimum amount of starch ( $1 \mathrm{~mL}$ of $1 \%$ starch).

3.3. Method Validation. The proposed methods have been validated for linearity, sensitivity, selectivity, precision, accuracy, and recovery according ICH guidelines [43].

3.3.1. Linearity, Detection, and Quantification Limits. The reaction stoichiometry for the titrimetric procedure was $1: 3$ owing to the presence of two allylic groups and a secondary aromatic amine in STS and the range of quantification was 1.0-10.0 mg STS. A linear correlation was found between absorbance and concentration of STS in the spectrophotometric methods. Regression analysis of Beer's law data using the method of least squares was made to evaluate the slope $(b)$, intercept $(a)$, and the correlation coefficient $(r)$ and the calculated values are given in Table 2 . The graph showed negligible intercept and is described by the regression equation $y=a+b x$, where $y$ is the measured absorbance and $x$ concentration in $\mu \mathrm{g} \mathrm{mL}^{-1}$. The limits of detection (LOD) and quantification (LOQ), sensitivity parameters such as molar absorptivity, and Sandell sensitivity are also contained in Table 2.

3.3.2. Accuracy and Precision. The accuracy of an analytical method expresses the closeness between the reference value and the found value. Accuracy was evaluated as percentage relative error between the measured concentrations and taken concentrations for STS (Bias\%). The results obtained are compiled in Table 3 and show that the accuracy is good for the methods.

The precision of the method was calculated in terms of intermediate precision (intra-day and inter-day). Three different concentrations of STS were analyzed in seven 


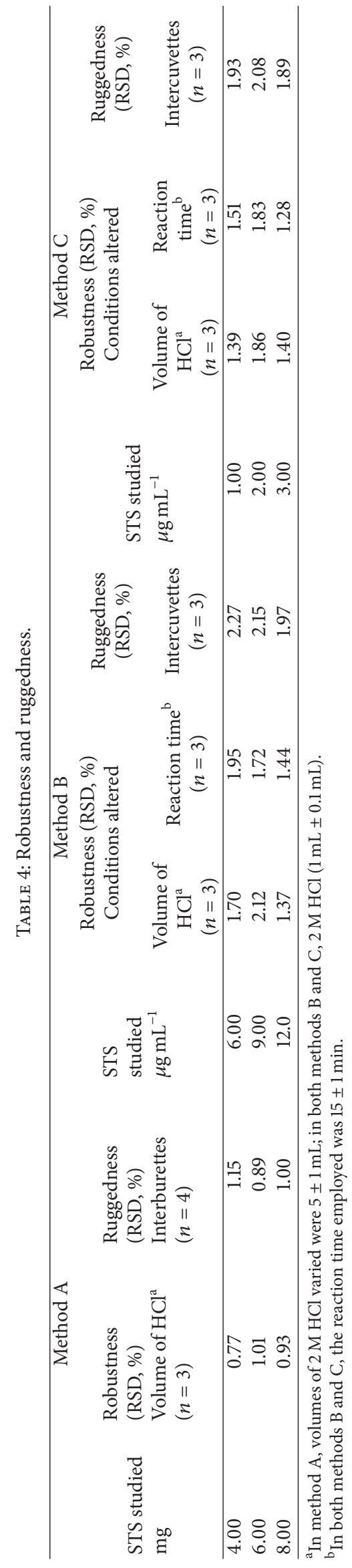


TABLE 5: Results of analysis of tablets by the proposed methods.

\begin{tabular}{|c|c|c|c|c|c|}
\hline \multirow{3}{*}{ Tablet brand name } & \multirow{3}{*}{$\begin{array}{l}\text { Label claim } \\
\mathrm{mg} / \text { tablet }\end{array}$} & \multicolumn{4}{|c|}{ Found (percent of label claim \pm SD) ${ }^{\mathrm{a}}$} \\
\hline & & \multirow{2}{*}{ Reference method } & \multicolumn{3}{|c|}{ Proposed methods } \\
\hline & & & Method A & Method B & Method C \\
\hline \multirow{3}{*}{ Suminat-25 } & \multirow{3}{*}{25} & \multirow{3}{*}{$101.1 \pm 0.83$} & $99.52 \pm 1.19$ & $101.6 \pm 1.45$ & $101.8 \pm 1.20$ \\
\hline & & & $t=2.44$ & $t=0.67$ & $t=1.07$ \\
\hline & & & $F=2.06$ & $F=3.05$ & $F=2.09$ \\
\hline \multirow{3}{*}{ Suminat-50 } & \multirow{3}{*}{50} & \multirow{3}{*}{$99.43 \pm 1.05$} & $100.9 \pm 0.81$ & $101.2 \pm 1.77$ & $99.09 \pm 1.83$ \\
\hline & & & $t=2.48$ & $t=1.92$ & $t=0.36$ \\
\hline & & & $F=0.60$ & $F=2.84$ & $F=3.04$ \\
\hline
\end{tabular}

${ }^{\mathrm{a}}$ Mean value of five determinations.

Tabulated $t$-value at the $95 \%$ confidence level is 2.78 .

Tabulated $F$-value at the $95 \%$ confidence level is 6.39 .

replicates during the same day (intra-day precision) and five consecutive days (inter-day precision). The RSD (\%) values of intra-day and inter-day studies showed that the precision was good (Table 3).

3.3.3. Robustness and Ruggedness. To evaluate the robustness of the methods, volume of $\mathrm{HCl}$ was slightly altered $(5 \pm 1 \mathrm{~mL})$ with reference to optimum values in titrimetry. However, in spectrophotometry, the reaction time (after adding NBS, time varied was $15 \pm 1 \mathrm{~min}$ in both methods $\mathrm{B}$ and $\mathrm{C}$ ) and volume of $2 \mathrm{M} \mathrm{HCl}$ were slightly altered $(1 \pm 0.1 \mathrm{~mL})$ in both $\mathrm{B}$ and $\mathrm{C}$ methods. To check the ruggedness, analysis was performed using four different burettes in method $\mathrm{A}$ and three different cuvettes in methods $\mathrm{B}$ and $\mathrm{C}$. The robustness and the ruggedness were checked at three different drug levels $\left(4,6,8 \mathrm{mg}\right.$ in method $\mathrm{A} ; 6,9,12 \mu \mathrm{g} \mathrm{mL} \mathrm{m}^{-1}$ in method $\mathrm{B}$; and $1,2,3 \mu \mathrm{g} \mathrm{mL}^{-1}$ in method $\mathrm{C}$ ). The intermediate precision, expressed as percent RSD, which is a measure of robustness and ruggedness, was within the acceptable limits (0.89$2.27 \%$ ) as shown in Table 4.

3.3.4. Selectivity. The proposed methods were tested for selectivity by placebo blank and synthetic mixture analyses. A convenient aliquot of the placebo blank solution, prepared as described earlier, was subjected to analysis by titrimetry and spectrophotometry according to the general procedures. In all the cases, there was no interference by the inactive ingredients present in the placebo mixture.

A separate experiment was performed with the synthetic mixture. The analysis of synthetic mixture solution prepared earlier yielded percent recoveries which ranged from 98.77 to 102.6 with standard deviation of $0.89-1.74$ in all the cases. The results of this study indicate that the inactive ingredients present in the synthetic mixture did not interfere in the assay. These results further demonstrate the accuracy, as well as the precision, of the proposed methods.

3.3.5. Application to Tablets Analysis. The proposed methods were applied to determine STS in same brand of tablets with two different doses. The results were statically compared with those obtained by the published reference method [12] for accuracy and precision by applying the Student's $t$-test and variance ratio $F$-test. The published reference method describes UV-spectrophotometric method for detection of STS in tablet formulation at $220 \mathrm{~nm}$. Statistical analysis of the results using Student's $t$-test for accuracy and F-test for precision revealed no significant difference between the proposed methods and the reference method at the $95 \%$ confidence level with respect to accuracy and precision (Table 5).

3.3.6. Recovery Studies. The accuracy and validity of the proposed methods were further ascertained by performing recovery studies. Preanalysed tablet powder was spiked with pure STS at three concentration levels (50\%, 100\%, and 150\% of that in tablet powder) and the total was found by the proposed methods. The added STS recovery percent values ranged between $98.20 \%$ and $103.0 \%$ with a standard deviation of $0.05-1.56$. The results of this study given in Table 6 indicated that the recovery was good, and that the coformulated substances did not interfere in the determination.

\section{Conclusions}

Three simple, sensitive, and selective methods are described for the determination of STS in tablets employing NBS as the brominating reagent. Titrimetry is applicable over 1.0$10.0 \mathrm{mg}$ range, and it is the first titrimetric method has ever been reported for the assay of STS in pharmaceuticals. The proposed spectrophotometric methods are characterized by high sensitivity and stability of the measured colored species. The proposed spectrophotometric methods are more sensitive than most of the reported methods in terms of both linear range and molar absorptivity. The proposed methods are simple, rapid, economic, and not involved in strict $\mathrm{pH}$ control and use of organic solvents, whereas most of the reported methods require rigid $\mathrm{pH}$ control, extraction step, and multistep reactions. Besides, the methods possess adequate accuracy and precision, and no interference from 


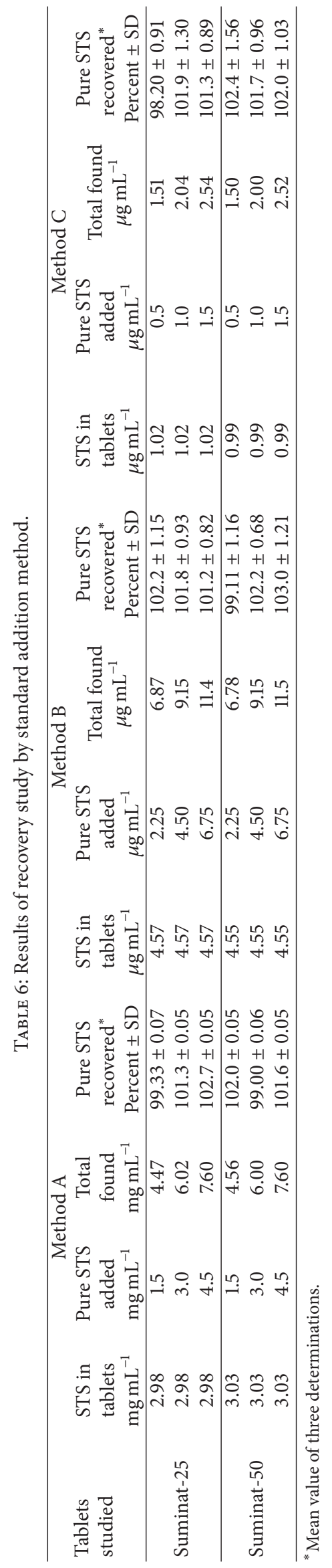


the excipients and coating materials was found. Hence, the methods can be employed for routine analysis in quality control laboratories.

\section{Acknowledgments}

The authors thank the authorities of the University of Mysore, Mysore, for permission and facilities. Authors thank MSN laboratories, Hyderabad, India, for gifting pure STS. They do not have any conflict of interests with the commercial identities mentioned in the paper.

\section{References}

[1] British Pharmacopoeia, Her Majesty's Stationery Office, vol. 2, London, UK, 1964.

[2] Conquering headache, Alan M.Rapoport, Decker DTC Hamilton, London, UK, 4th edition, 2003.

[3] European Pharmacopoeia, EDQM Council of Europe, vol. 2, Staranborg, France, 2007.

[4] The United States Pharmacopoeia, USP Convention, INC, Twinbrook, 12th edition, 2004.

[5] Z. Ge, E. Tessier, L. Neirinck, and Z. Zhu, "High performance liquid chromatographic method for the determination of sumatriptan with fluorescence detection in human plasma," Journal of Chromatography B, vol. 806, no. 2, pp. 299-303, 2004.

[6] M. Franklin, J. Odontiadis, and E. M. Clement, "Determination of sumatriptan succinate in human plasma by highperformance liquid chromatography with coulometric detection and utilization of solid-phase extraction," Journal of Chromatography $B$, vol. 681, no. 2, pp. 416-420, 1996.

[7] M. Dunne and P. Andrew, "Fully automated assay for the determination of sumatriptan in human serum using solidphase extraction and high-performance liquid chromatography with electrochemical detection," Journal of Pharmaceutical and Biomedical Analysis, vol. 14, no. 6, pp. 721-726, 1996.

[8] R. Sheshala, N. Khan, and Y. Darwis, "Validated high performance liquid chromatography (HPLC) method for the determination of sumatriptan in rabbit plasma: application to pharmacokinetic study," Journal of Pharmacy and PharmacologyNo, vol. 6, no. 2, pp. 98-107, 2012.

[9] P. D. Andrew, H. L. Birch, and D. A. Phillpot, "Determination of sumatriptan succinate in plasma and urine by high- performance liquid chromatography with electrochemical detection," Journal of Pharmaceutical Sciences, vol. 82, no. 1, pp. 73-76, 1993.

[10] K. N. Cheng, M. J. Redrup, A. Barrow, and P. N. Williams, "Validation of a liquid chromatographic tandem mass spectrometric method for the determination of sumatriptan in human biological fluids," Journal of Pharmaceutical and Biomedical Analysis, vol. 17, no. 3, pp. 399-408, 1998.

[11] J. Oxford and M. S. Lant, "Development and validation of a liquid chromatographic-mass spectrometric assay for the determination of sumatriptan in plasma," Journal of Chromatography, vol. 496, no. 1, pp. 137-146, 1989.

[12] A. E. Prabahar, R. Kalaichelvi, B. Thangabalan, R. Karthikeyan, C. Prabhakar, and P. V. Kumar, "Validated spectroscopic method for estimation of sumatriptan succinate in pure and from tablet formulation," Research Journal of Pharmacy and Technology, vol. 2, no. 3, pp. 495-497, 2009.

[13] R. P. Gondalia and A. P. Dharamsi, "Spectrophotometric simultaneous estimation of sumatriptan succinate and naproxen sodium in tablet dosage forms," Asian Journal of Pharmaceutical and Clinical Research, vol. 4, no. 2, pp. 31-32, 2011.

[14] M. R. Pourmand, M. S. Azar, and M. Aghavalijamaat, "Development of validated UV spectrophotometric method for in vitro analysis of sumatriptan in pharmaceutical preparations in comparison with HPLC," Pharmaceutical Chemistry Journal, vol. 44, no. 10, pp. 585-589, 2011.

[15] M. Trinath, S. K. Banerjee, H. D. Teja, and C. G. Bonde, "Development and validation of spectrophotometric method for simultaneous estimation of sumatriptan and naproxen sodium in tablet dosage form," Der Pharmacia Sinica, vol. 1, no. 1, pp. 36-41, 2010.

[16] L. I. Bebawy, A. A. Moustafa, and N. F. Abo-Talib, "Stabilityindicating methods for the determination of sumatriptan succinate," Journal of Pharmaceutical and Biomedical Analysis, vol. 32, no. 6, pp. 1123-1133, 2003.

[17] A. B. Avadhanulu, J. S. Srinivas, and Y. Anjaneyulu, "Reverse phase HPLC and colorimetric determination of sumatriptan succinate in its drug form," Indian Drugs, vol. 33, no. 7, pp. 334337, 1996.

[18] V. A. Shirsat, S. Y. Gabhe, and S. G. Deshpande, "High performance liquid chromatographic determination of sumatriptan succinate from pharmaceutical preparation," Indian Drugs, vol. 35, no. 7, pp. 404-407, 1998.

[19] S. Singh and R. Jain, "Stability indicating HPLC method for the determination of sumatriptan succinate in pharmaceutical preparations and its application in dissolution rate studies," Indian Drugs, vol. 34, no. 9, pp. 527-531, 1997.

[20] N. Badwe, N. Sharma, and N. Agarwal, "HPLC determination of sumatriptan succinate in pharmaceutical dosage forms," Eastern Pharmacist, vol. 40, no. 475, pp. 121-122, 1997.

[21] Y. R. Reddy, K. K. Kumar, M. R. P. Reddy, and K. Mukkanti, "Rapid simultaneous determination of sumatriptan succinate and naproxen sodium in combined tablets by validated ultra performance liquid chromatographic method," Journal of Analytical \& Bioanalytical Techniques, vol. 2, no. 3, pp. 1-6, 2011.

[22] D. N. Tipre and P. R. Vavia, "Estimation of Sumatriptan succinate in pharmaceutical dosage form by spectrophotometric and HPTLC method," Indian Drugs, vol. 36, no. 8, pp. 501-505, 1999.

[23] K. D. Altria and S. D. Filbey, "Quantitative determination of sumatriptan by capillary electrophoresis," Analytical Proceedings, vol. 30, no. 9, pp. 363-365, 1993.

[24] K. M. Al Azzam, B. Saad, C. Y. Tat, I. Mat, and H. Y. AboulEnein, "Stability-indicating micellar electrokinetic chromatography method for the analysis of sumatriptan succinate in pharmaceutical formulations," Journal of Pharmaceutical and Biomedical Analysis, vol. 56, no. 5, pp. 937-943, 2011.

[25] K. Sagar, J. M. Fernandez Alvarez, C. Hua, M. R. Smyth, and R. Munden, "Differential pulse voltammetric determination of sumatriptan succinate (1:1) in a tablet dosage form," Journal of Pharmaceutical and Biomedical Analysis, vol. 10, no. 1, pp. 17-21, 1992.

[26] S. Shahrokhian, Z. Kamalzadeh, and R.-S. Saberi, "Glassy carbon electrode modified with a bilayer of multi-walled carbon nanotube and polypyrrole doped with new coccine: application to the sensitive electrochemical determination of Sumatriptan," Electrochimica Acta, vol. 56, no. 27, pp. 10032-10038, 2011.

[27] M. Amiri, Z. Pakdel, A. Bezaatpour, and S. Shahrokhian, "Electrocatalytic determination of sumatriptan on the surface of carbon-paste electrode modified with a composite of cobalt/Schiff-base complex and carbon nanotube," Bioelectrochemistry, vol. 81, no. 2, pp. 81-85, 2011. 
[28] B. Kalyanaramu and K. Raghubabu, "Visible spectrophotometric methods for the estimation of sumatriptan succinate in bulk and dosage forms," Acta Ciencia Indica, Chemistry, vol. 37, no. 2, pp. 143-147, 2011.

[29] B. Kalyanaramu and K. Raghubabu, "A simple visible spectrophotometric determination of sumatriptan succinate from pharmaceutical formulations," Der Pharma Chemica, vol. 3, no. 1, pp. 223-228, 2011.

[30] B. K. Ramu and K. Raghubabu, "A simple colorimetric determination of sumatriptan succinate from tablet dosage forms using cobalt thio cyanate," International Journal of Pharmacy and Technology, vol. 3, no. 1, pp. 1411-1418, 2011.

[31] B. Kalyana Ramu and K. Raghubabu, "Ion association method for the determination of sumatriptan succinate from tablet dosage forms using tropaeolin OOO," International Journal of Pharmacy and Pharmaceutical Sciences, vol. 3, no. 3, pp. 175178, 2011.

[32] B. Kalyanaramu, G. Rupakumari, K. Ramarao, and K. Raghubabu, "Development of new visible spectrophotometric methods for quantitative determination of sumatriptan succinate based on charge-transfer complex formation," International Journal of Pharmacy and Pharmaceutical Science Research, vol. 1, no. 2, pp. 47-51, 2011.

[33] A. Fathima, S. Rao, and G. Venkateshwarlu, "Quantitative determination of drugs \& pharmaceuticals using $p$-chloranilic acid as reagent," International Journal of ChemTech Research, vol. 4, no. 1, pp. 79-91, 2012.

[34] B. Kalyanaramu and K. Raghubabu, "Visible spectrophotometric determination of sumatriptan succinate in tablet dosage forms using folin reagent," International Journal of Pharmaceutical Biomedcal SciencesNo, vol. 1, no. 3, pp. 49-52, 2010.

[35] D. N. Tipre and P. R. Vavia, "Estimation of Sumatriptan succinate in pharmaceutical dosage form by spectrophotometric and HPTLC method," Indian Drugs, vol. 36, no. 8, pp. 501-505, 1999.

[36] K. V. V. Satyanarayana and P. N. Rao, "Sensitive bromatometric methods for the determination of sumatriptan succinate in pharmaceutical formulations," E-Journal of Chemistry, vol. 8, no. 1, pp. 269-275, 2011.

[37] A. Berka, J. Vulterin, and J. Zyka, Newer Redox Titrants, Pergamon Press, New York, NY, USA, 1965.

[38] N. K. Mathur and C. K. Narang, The Determination of Organic Compounds With N-Bromosuccinimide and Allied Reagents, Academic Press, New York, NY, USA, 1975.

[39] K. B. Vinay, H. D. Revanasiddappa, O. Z. Devi, P. J. Ramesh, and K. Basavaiah, "Rapid titrimetric and spectrophotometric determination of ofloxacin in pharmaceuticals using $N$ bromosuccinimide," Brazilian Journal of Pharmaceutical Sciences, vol. 47, no. 2, pp. 251-260, 2011.

[40] O. Zenita and K. Basavaiah, "Utility of $N$-bromosuccinimide for the titrimetric and spectrophotometric determination of famotidine in pharmaceutical formulations," International Journal of Analytical Chemistry, vol. 2011, Article ID 581372, 11 pages, 2011.

[41] K. N. Prashanth and K. Basavaiah, "Sensitive and selective methods for the determination of rizatriptan benzoate in pharmaceuticals using $N$-bromosuccinimide and two dyes," Journal of Saudi Chemical Society, vol. 2012, 2012.

[42] R. T. Morison and R. N. Boyd, Organic Chemistry, Prentice-Hall Inc. Upper Saddle River, New Jersey, NJ, USA, 6th edition, 1992.

[43] Pharmaceuticals for Human Use, ICH Harmonized Tripartite Guideline, Validation of Analytical Procedures: Text and
Methodology Q2(R 1), Complementary Guideline on Methodology dated 06 November 1996, incorporated in November 2005, London. 

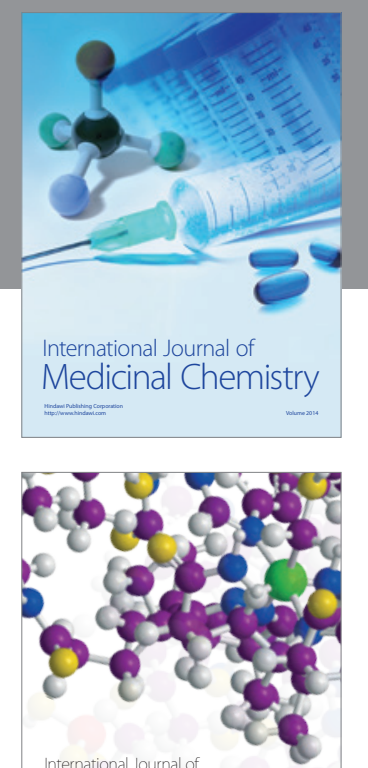

\section{Carbohydrate} Chemistry

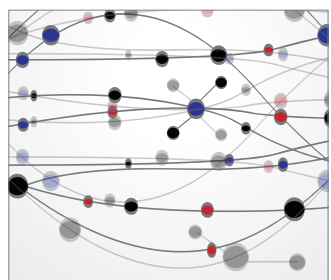

The Scientific World Journal
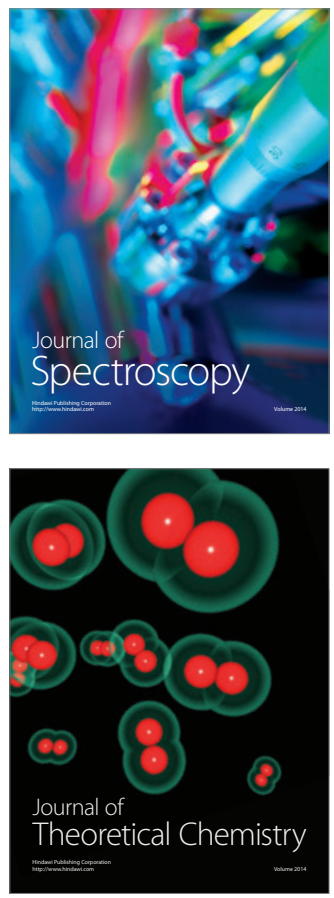
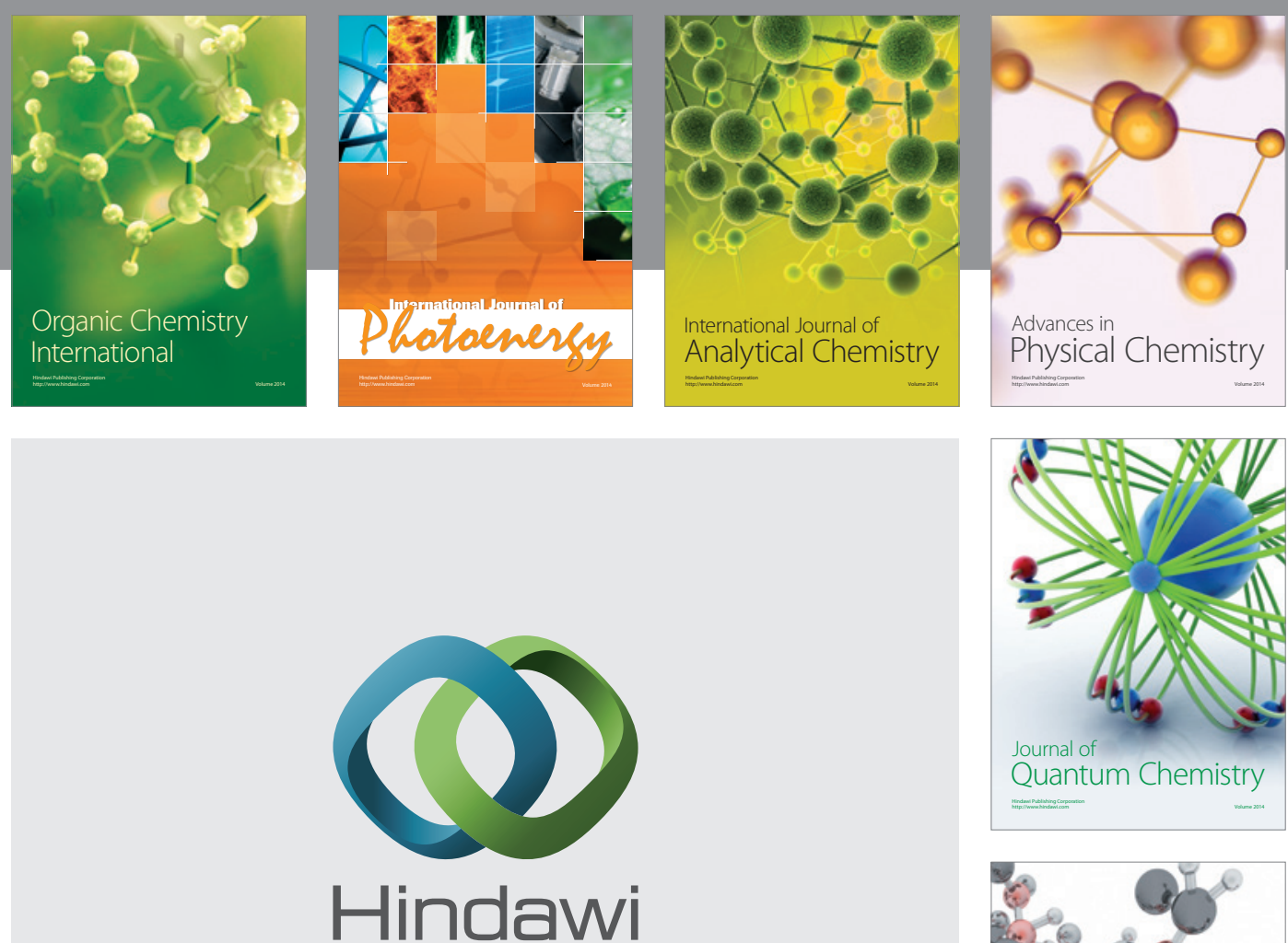

Submit your manuscripts at

http://www.hindawi.com

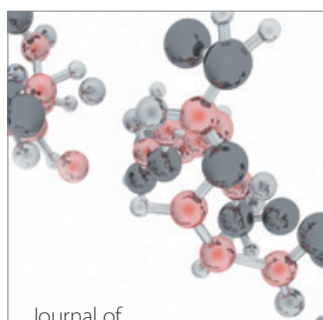

Analytical Methods

in Chemistry

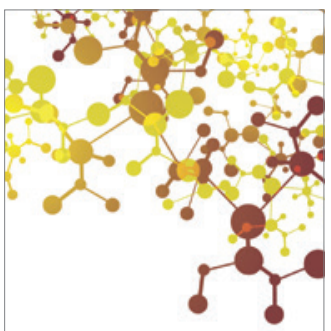

Journal of

Applied Chemistry

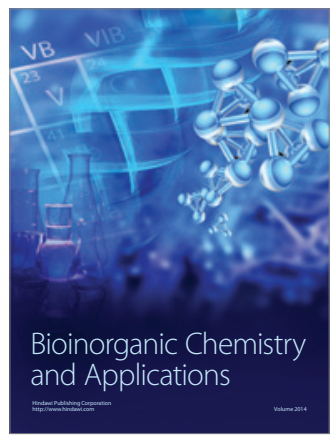

Inorganic Chemistry
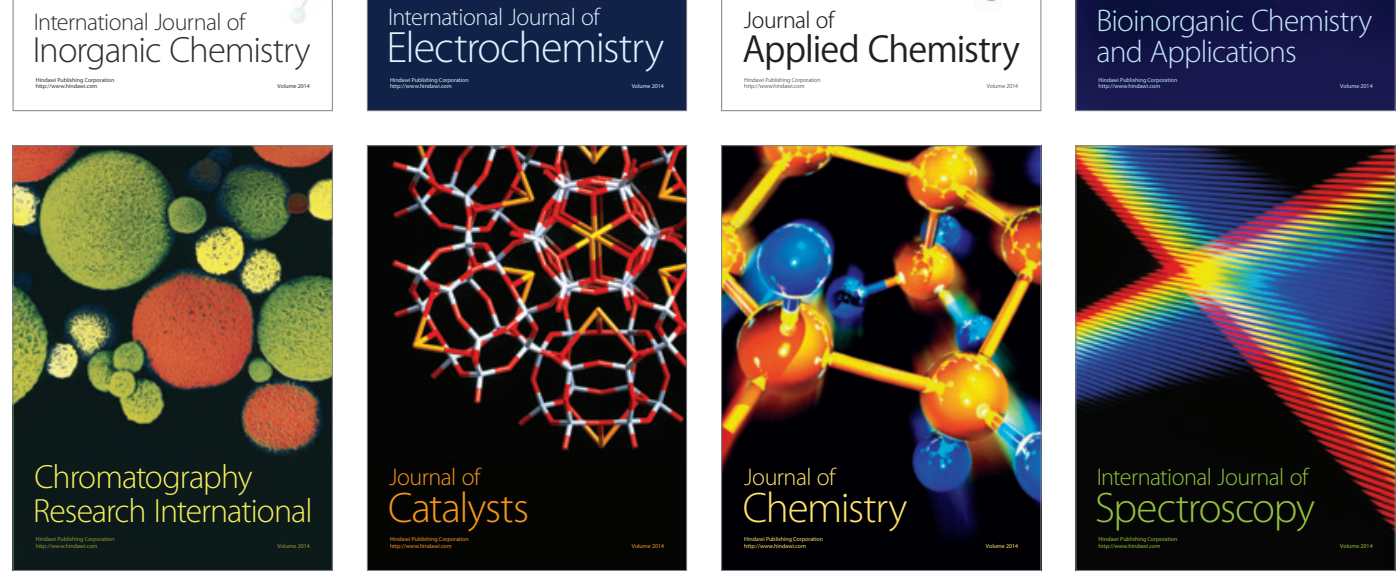